\title{
THE EFFECTS OF BOREOUT ON STRESS, DEPRESSION, AND ANXIETY IN THE WORKPLACE
}

Fahri ÖZSUNGUR ${ }^{1}$

\section{ABSTRACT}

Keywords:

Boreout

Depression

Anxiety

Stress

Chambers Of Commerce

JEL Codes:

O15, L84, L44

\author{
Received Date (Başvuru Tarihi): \\ Accepted Date (Kabul Tarihi): \\ Published Date (Yayın Tarihi):
}

$30 / 03 / 2020$
$14 / 05 / 2020$
$25 / 06 / 2020$

$30 / 03 / 2020$
$14 / 05 / 2020$
$25 / 06 / 2020$

$30 / 03 / 2020$
$14 / 05 / 2020$
$25 / 06 / 2020$
The study aims to determine the effects of boreout on employee's depression, anxiety, and stress levels. Furthermore, it is aimed to reveal employee's job meaningless, employee's job boring, stress factors, ways of coping and being happy under stress via interview. This study was conducted with 186 participants recruited from the Chambers of Commerce in Turkey. Mixed-Method Evaluation Design has been adopted in the study based on the social exchange theory, which includes quantitative and qualitative analysis methods. Findings revealed a positive association between boreout, depression, stress, and anxiety. The coding findings confirmed the three-dimensional structure of the boreout scale those were the problems arising from managers, employees and working conditions. Furthermore, stress was perceived by the employees as three main effects in terms of keeping away, accepting and struggling.

\section{BOREOUT'UN ISŞ YERINDE STRES, DEPRESYON VE ANKSIYYETE ÜZERİNDEKİ ETKİLERİ}

$\ddot{O Z Z}$

Anahtar Kelimeler:

Boreout

Depresyon

Anksiyete

Stres

Ticaret Odalarn

JEL Kodlari:

O15, L84, L44
Çalışma, boreout'un işgören depresyonu, anksiyete ve stres düzeyleri üzerindeki etkilerini belirlemeyi amaçlamaktadır. Ayrıca, işgörenin işini anlamsız kılan, çalışanın işini sıkıcı yapan faktörler, stres faktörleri, bunlarla baş etme yolları ve stres altında mutlu olma durumların ortaya koymayı hedeflemektedir. Bu çalışma, Türkiye'de Ticaret Odalarında çalışan 186 katılımo ile gerçekleştirilmiş̧ir. Araştırmada nicel ve nitel analiz yöntemlerini içeren sosyal değişim teorisine dayanan karma yöntem değerlendirme tasarım benimsenmiştir. Bulgular boreout, depresyon, stres ve anksiyete arasında pozitif bir ilişki olduğunu ortaya koymuştur. Kodlamaya dair bulgular yöneticiler, işgörenler ve çalışma koşullarından kaynaklanan problemler olan boreout ölçeğinin üç boyutlu yapısını doğrulamıştır. Ayrıca, stres işgörenler tarafindan uzak durma, kabul etme ve mücadele etme anlamında üç ana etki olarak algılanmıştır.

${ }^{1}$ Av. Dr., Adana Alparslan Türkeş Bilim ve Teknoloji Üniversitesi, ticaretsicili@gmail.com,

http://orcid.org/0000-0001-6567-766X 


\section{INTRODUCTION}

Employees develop a career, gains earnings and interacts with the social and business network of the businesses in workplaces that takes place an important place in today's economy. Thanks to this network, individuals prefer a large part of their time spent in workplaces more than their families. Expectations from the workplace and managers are revealed in return for this preference. Expectations create an important social exchange cycle between the individual and the organization (Blau, 1964). The benefit provided and the benefit obtained in exchange cause comparison and syllogize in the cognitive process. The individual is also affected by many factors in the workplace while comparing the benefit and harm in the cognitive process (Foster et al., 2020).

The workplace contributes to the cognitive process and is an important determinant in the development of behaviors and in triggering the psychological state (Cangialosi, Odoardi, \& Battistelli, 2020). The fact that the activities carried out in the workplace affect human psychology significantly brings the benefit judgment to be achieved with social exchange to the forefront (Zagenczyk et al., 2020). At this stage, the problems related to the job, the obligation of the individual to perform the job for the financial reasons in the face of finding the job meaningless, despite the job boredom to achieve the intended result triggers certain conflicts (Santiago, Vega, \& Alvarado, 2020). These conflicts can result in psychological negative or positive conditions. Boreout is one of the negative aspects of these psychological states. Bore-out consists of three basic factors: crisis of growth, a crisis of meaning at work, and job boredom (Stock, 2015). This syndrome causes the employees to perceive their work as meaningless in their workplace, their belief that they do not have career opportunities, and that they have significant problems focusing on work (Bailey \& Madden, 2016). This negative state can cause the individual to face anxiety and stress (Jones et al., 2018). Especially, the fact that executives ignore the employees, do not support the career development, problems related to human resources management, merit deficiencies affect the employees' problems about their duties and positive thoughts about the workplace. Thus, the employee gets bored with her/his work and workplace and is disappointed about her/his plans (Stock, 2015). However, the studies do not 
include any qualitative and mixed findings about why individuals find their jobs meaningless and get bored with their jobs. The complex cognitive structure of the human being, the unidentified triggers between his behavior and his psychological state suggest the following two questions:

Q1. What makes employee's job meaningless?

Q2. What makes employee's job boring?

The employee who faced with psychological and physical harassment, discrediting and ignoring, can find his/her job meaningless. The boreout, which derives its foundation from Dutton, Roberts and Bednar's (2010) personal identity theory, refers to the distinction between acceptance of the individual as both a social and biological entity. Beyond biological needs, the needs of being a social being assign a different identity to people. This perception of identity enriches individual expectations and allows them to adapt to social life or be excluded from society. At this point the "boreout" manifests itself. Negative work behaviors occur when the individual has difficulty in demarcating the boundary between his/her biological and social identity. This interaction may cause the employee to face with boreout (Stock, 2015). Boredom, career problems, and the meaning attributed to work do not arise spontaneously. This emerges through the interaction between business, the leader/executive and the employee. Experience, interaction, communication and perception are the most important factors in the emergence of boreout. Stock (2015) revealed that negative states related to career and meaning were negatively associated with the individual's innovative work behavior. The same author found that there was a negative relationship between customer-oriented behavior and the three dimensions of boreout. These findings show that boreout can cause negative attitudes and behaviors in the workplace. However, the findings do not provide evidence of the association between boreout, stress, depression, and anxiety. In the literature, there is no study examining the relationship between boreout, stress, depression and anxiety. There was no empirical study on the effects of boreout on individuals' stress, depression, and anxiety. It is thought that the investigation of the boreout conditions of employees in the workplace by qualitative and quantitative methods will provide to reveal the problems via in-depth analysis. 
Depression is a state of mental disorder in which dysphoria, hopelessness, devaluation of life, self-deprecation, lack of interest or involvement, anhedonia, inertia symptoms are observed (Lovibond \& Lovibond, 1995). These symptoms can also be seen as feeling downhearted and blue, sad and depressed, life meaningless, pretty worthless, become enthusiastic about anything, lack of positive feeling, lack of enjoyment (Lovibond \& Lovibond, 1995). These negative affective states occur in the workplace for certain reasons. Studies revealed that wages, health insurance, and workload had depressive effects on teachers (Roberts et al., 2019). Besides, there was an association between depression and depletion productivity (Swindle, Kroenke, \& Braun, 2001), presenteeism and workplace absenteeism (Evans-Lacko et al., 2016), smoking status (Halpern, Khan \& Rentz, 2001). In particular, it is suggested whether the negative symptoms with depression are associated with boreout. Boreout's feelings of boredom, meaninglessness, and anxiety inspire the association with depression.

$\boldsymbol{H}_{1}$ : Boreout is positively associated with depression.

Anxiety is a state of psychological disorder in which autonomic arousal, skeletal musculature effects, phobias, subjective experience of anxious affect and panic disorders are observed (Lovibond \& Lovibond, 1995). Clercq, Haq, and Azeem (2018) revealed the mediating role of anxiety on the association between self-efficacy and job performance. Another study found the association between anxiety and absenteeism (Olive \& Cangemi, 2015). In the face of this association with negative states, the association between anxiety and assigning meaning of the employee to the job and job boredom should be investigated. A person exposed to boreout is likely to be confronted with humiliation, rejection from a group in the workplace (Zellars, 2007). Therefore, boreout is thought to have a positive relationship with anxiety.

$\mathbf{H}_{2}$ : Boreout is positively associated with anxiety.

Stress is a mental state that has a positive or negative effect on an individual's performance and behavior (Statt, 2004). Stress is a state of difficulty relaxing, nervous arousal, easily upset or agitated and impatient (Lovibond \& Lovibond, 1995). Stress leads to a reduction in efficiency, reduced self-actualization and taking initiative, and weakening relationships with colleagues (Fairbrother \& Warn, 2003). However, it is possible to mention the positive effects of stress as far as absorption and goal is 
concerned. Some individuals may choose to struggle with the problems. When the consciousness of struggle occurs, the hypothalamus sends a signal to the pituitary gland and secretes adrenaline. The individual focuses on coping with stress with these signals (Buchanan \& Huczynski, 2004). However, this positive effect often affects the quality of life of employees negatively and negative impacts also occur (LeFevre et al., 2003).

Studies have shown a relationship between stress and many factors in the workplace. Former studies revealed an association between stress and mental ill health (Sparks \& Cooper, 1999; Siegrist, 1998), role conflict (Burke, 1988), physical conditions (Burke, 1988), job satisfaction (Tett \& Meyer, 1993; Sullivan \& Bhagat, 1992; Williams \& Hazer, 1986; Leong et al., 1996), life satisfaction (Tonsing, 2014), work overload (Sparks \& Cooper, 1999; DeFrank \& Ivancevich, 1998), social environment (Sparks \& Cooper, 1999), leader effect (Carlopio, Andrewartha, \& Armstrong, 1997), career development (Nelson \& Burke, 2000), job performance (Sullivan \& Bhagat, 1992), organizational commitment (Williams \& Hazer, 1986; Naumann, 1993; Tett \& Meyer, 1993), autonomy and work stress (Wolfe \& Patel, 2019), job satisfaction and burnout (Embriaco et al, 2007; Leiter, Bakker \& Maslach, 2014), employee negative behavior and transformational leadership (Yao et al., 2014), work load (Løkke \& Madsen, 2014). Løkke and Madsen, (2014) in a study conducted in the public sector, showed that senior managers experienced less stress than other managers and employees. This finding reveals that the stress state has changed according to organizational status. Meaningfulness of work restrains the association between stress and autonomy in the workplace (Wolfe \& Patel, 2019).

$\mathbf{H}_{3}$ : Boreout is positively associated with stress.

Q3. What are the most important factors that cause an employee to be stressed in the workplace?

Q4. What does an employee do to get rid of stress at work?

Q5. What does an employee do to be happy under stress?

The aim of the study is to determine the effects of boreout on employee's depression, anxiety, and stress levels. Furthermore, it is aimed to reveal employee's 
job meaningless, employee's job boring, stress factors, ways of coping and being happy under stress via interview.

\section{METHODS}

\subsection{Participant}

According to the 2018 workforce data obtained from the Insurance and Retirement Fund Foundation of the Union of Chambers and Commodity Exchanges of Turkey, there were a total of 1725 employees (988 male, 737 female). The questionnaire was created in a virtual environment via Google Forms. The questionnaires were sent to 566 employees through the general secretariats and websites of the relevant chambers of commerce via e-mail. 186 questionnaires were received at the rate of $10 \%$ of the universe.

Participants $(\mathrm{N}=186)$ were selected from the Chambers of Commerce in Turkey in January 2019. Participants were working as employees offering services in chambers of commerce operating in the province of Ankara, Adana, Izmir, and Istanbul in Turkey. On the other hand, participants were informed that participation in the questionnaire was voluntary and that it could be terminated at every stage of the study and signed the consent form.

\subsection{Measures}

Boreout (BRT) scale developed by Stock (2015) was used in the study. This scale consists of 11 items and 3 dimensions. These dimensions are as follows: the crisis of meaning at work (4 items) (CMW) (Schnell, 2010), job boredom (3 items) (JB) (Fisher, 1998), the crisis of growth (4 items) (CG) (Bakker, van Veldhoven, \& Xanthopoulou, 2010). The scale is measured using the 7-point Likert scale. The dimension of CG is conversely measured relative to other dimensions. Because this dimension has a positive meaning compared to others. Turkish validity and reliability of the scale have not been performed before. The validity and reliability of the scales were determined according to the confirmatory factor analysis results obtained in this study [X2 (186): 595,828, p > .01; Х2/ df: 1,850; SRMR: ,033; RMSEA: ,064; NNFI: ,923; IFI: ,935; CFI: ,934; GFI: ,839; AGFI: ,796]. The Cronbach's Alpha values of the scales were measured as follows $($ stress $=.938$; depression $=.901$; anxiety $=.890$; boreout $=.842)$. On the other 
hand, the scale was previously studied in Turkish (Özsungur, 2020; Karadal, Abubakar, \& Erdem, 2018).

The Depression Anxiety Stress Scale-21 (DASS-21) consisted of 21 items (selfreport questions)measured the dimensions regarding depression (DASS-Depression), anxiety (DASS-Anxiety) and stress (DASS-Stress). These subscales rated on a fourpoint Likert type scale to measure the frequency of depression, anxiety, and stress symptoms over the past week. Seven items measured DASS-Depression comprised of dysphoria, hopelessness, devaluation of life, self-deprecation, lack of interest/involvement, anhedonia, and inertia symptoms. Seven items measured DASS-Anxiety comprised of Autonomic arousal, Skeletal musculature effects, Situational anxiety, Subjective experience of anxious effect. Seven items measured DASS-Stress comprised of difficulty relaxing, nervous arousal, easily upset/agitated, irritable/over-reactive, impatient. Each subscale included seven items rating on a fourpoint scale ranging from 0 (Strongly Disagree) to 3 (Totally Agree). Items were summed up to create a total DASS-21 score. Yildırım, Boysan, and Kefeli (2018) developed the Turkish version of the DASS-21 that the Turkish version of the scale had excellent internal reliability, with Cronbach's alphas ranging from 0.87 to 0.90 . They indicated that this scale had adequate psychometric properties in non-clinical samples.

\subsection{Procedure}

A mixed-method was adopted in the research. The mixed-method is a method in which quantitative and qualitative methods are applied together (Onwuegbuzie \& Leech, 2004). This method provides the evaluation, verification, and clarification of the results obtained by the quantitative method (Davies, 2000). The quantitative method is used to measure the level within certain limits with predefined questions. The qualitative method, on the other hand, provides the emergence of the causes and consequences of a particular phenomenon (Greene, Caracelli \& Graham, 1989). The mixed-method ensures that the missing aspects of both methods are completed. Therefore, it is a method recommended in the literature.

\subsection{Interview Questions}

In the qualitative research method, the data obtained were reported by coding, identification, classification and component analysis (Spradley, 1980). In cases where 
data need to be coded, the following analyzes in the coding process proposed by Miles and Huberman (1994) were used respectively. 1-Conceptualization: a) Reading and absorption the words, sentences, and paragraphs in the data set b) Linking the responses with the fields (management, personnel, etc.) of the researched subject c) Linking the subjects highlighted by the participants with the fields and determining the priority areas 2-Classification analysis: Classification of each field within itself: simplification of data, creation of themes (categories) by grouping related concepts, grouping themes close to each other. 3-Component analysis: Defining the properties of the state encoded under the theme and supporting these definitions with participatory data (Strauss \& Corbin, 1990). The analysis performed during the coding process was shown in Figure 1.

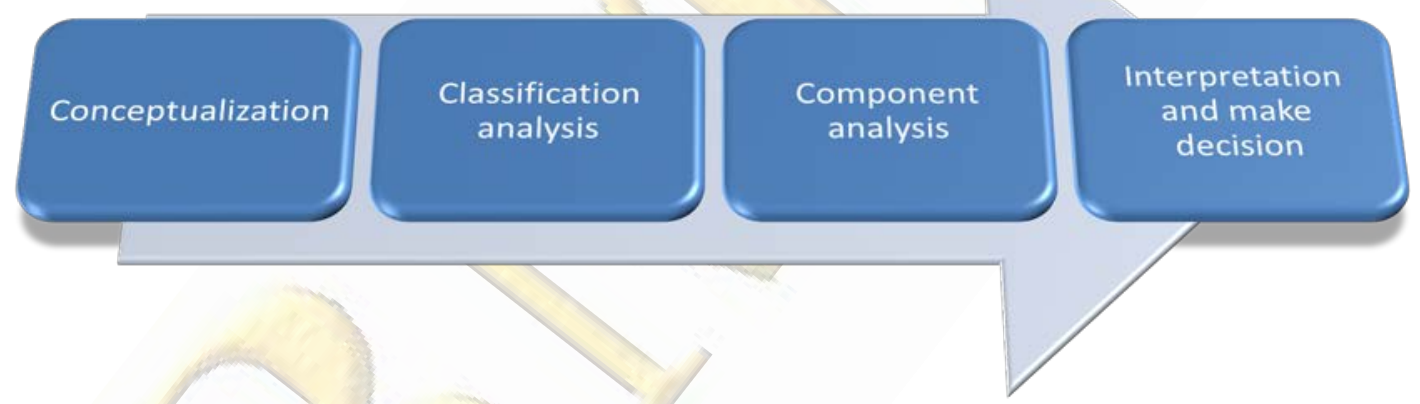

Figure 1. Analysis of Qualitative Data Coding Process

\subsection{Data Analysis}

Structural Equation Modeling (SEM) was implemented to analyze the findings of the study. SEM, implemented through the AMOS software, aims to reveal causal associations between the latent variables and observed variables (Hu \& Bentler, 1999; Gefen, Straub \& Boudreau, 2000). The coefficients to determine the good fit criteria of the model are as follows: $\chi 2, \chi^{2}$ / df, RMSEA, SRMR, GFI, AGFI, CFI, IFI, NNFI (TLI). 


\section{RESULTS}

\subsection{Demographics}

Demographic variables on participants' gender, age, marital status, education and manner of work level were presented in Table 1.

Table 1. Personal Demographic Variables Table

\begin{tabular}{|c|c|c|c|}
\hline \multicolumn{2}{|c|}{ Demographic variables } & \multirow{2}{*}{$\begin{array}{c}\mathbf{f} \\
72\end{array}$} & \multirow{2}{*}{$\begin{array}{r}\% \\
38.7\end{array}$} \\
\hline Gender & Female & & \\
\hline & Male & 114 & 61.3 \\
\hline \multirow[t]{7}{*}{ Age } & $18-23$ & 10 & 5.4 \\
\hline & $24-29$ & 36 & 19.4 \\
\hline & $30-35$ & 49 & 26.3 \\
\hline & $36-41$ & 48 & 25.8 \\
\hline & $42-47$ & 20 & 10.8 \\
\hline & $48-53$ & 16 & 8.6 \\
\hline & 54 and over & 7 & 3.8 \\
\hline Marital & Single* & 62 & 33.3 \\
\hline status & Married & 124 & 66.7 \\
\hline Education & High school graduate and & 25 & 13.4 \\
\hline \multirow[t]{6}{*}{ level } & less** & & \\
\hline & Associate's degree & 27 & 14.5 \\
\hline & Bachelor's degree & 116 & 62.4 \\
\hline & Master's degree & 18 & 9.7 \\
\hline & I offer service directly to the & 141 & 75.8 \\
\hline & customer & & \\
\hline Manner of & I do not offer service directly to & 45 & 24.2 \\
\hline Work & the customer & & \\
\hline
\end{tabular}

Note: *The statistical results of "widowed" and "divorced" participants were combined under "single": widowed (f=1;0.5\%); divorced $(\mathrm{f}=5 ; 2.7 \%)$, ** "Primary school graduate" results were included in the category of "High school graduate and less": primary school graduate $(\mathrm{f}=1 ; 0.5 \%)$. 
$38,7 \%$ of the participants were female and $61,3 \%$ were male. $71.5 \%$ of the participants were between the ages of $24-41$. $66,7 \%$ of the participants were married and $62,4 \%$ had bachelor's degree. The participants who offered services directly were $75,8 \%$.

\subsection{Construct Validity}

The harmony between the structure predicted in the social and behavioral sciences and the actual structure is determined by CFA. On the other hand, CFA allows the latent variables to be measured by the observed variables. CFA is used to test how well the measured variables represent the number of structures and is a multivariate type of statistical analysis (Brown, 2015). This statistical procedure provides confirmation of the theoretically proposed model (Field, 2005). Therefore, structural relationships related to direct and indirect effects should be verified with CFA regardless of the number of models (Kline, 2016). Scale items should be included in the analysis as the observed variable during validation with CFA (Hair et al., 2016). In the hypothesis test after model verification is performed, the averages of the scales are taken and the relationships are reported by testing the model values ( $\mathrm{Hu} \&$ Bentler, 1999). Therefore, these stages suggested in the literature were applied in the study. Estimated model of CFA is presented in Figure 2.

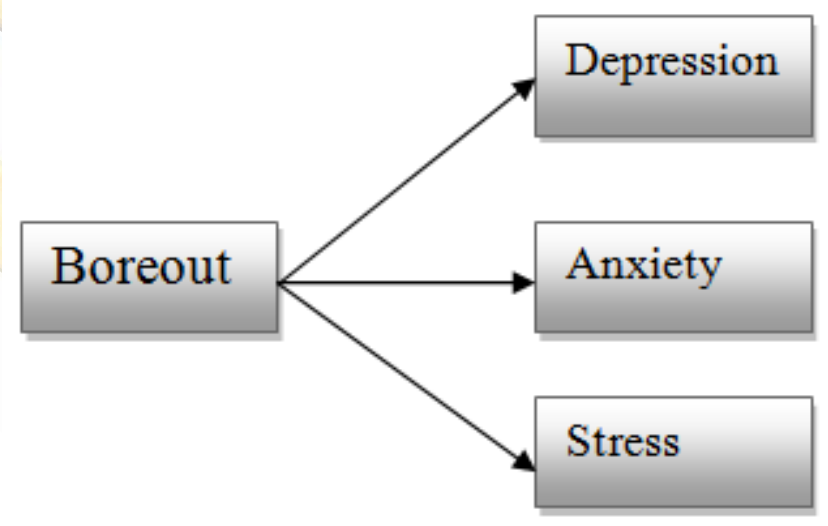

Figure 2. The Research Model

During the SEM analysis, the model did not show a good fit [ $\chi 2$ (186): 2338,806, $\mathrm{p}<.01$; $\chi^{2}$ /df: 5,041; SRMR: .681; RMSEA: .139; NNFI: .589; IFI: .618; CFI: 616; GFI: .489; AGFI: .419]. Initial model fit values are shown in Table 2. In CFA, the theoretical 
model must provide good fit values to be validated. Two methods are recommended in the literature to ensure good compliance values. The first is to discard items with low standardized regression weight from the model (Field, 2005; Stevens, 1992). The second path is to link items with high covariance loads (Brown, 2015). Discarding items is not be a preferred method. Because the items are the building blocks representing the model. For this reason, initially, it is recommended to link the items with covariance. Following this procedure, the standardized regression weights of Boreout and DASS-21 items (over 0,6) met the criteria and these items were not discarded from the model. As suggested in the literature, items with high covariance weights were linked. 6th and 7th items of depression scale, 2nd, 3rd, 4th, 5th items of the anxiety scale, $2 \mathrm{nd}, 3 \mathrm{rd}, 4 \mathrm{th}$, 5 th items of stress scale were linked to each other (Depression covariance MI: e27-e26 = 24,319; anxiety covariance MI: e24- e23 = 13,400; e22-e21 = 58,093; stress covariance MI: e17-e16 = 16,376; e15-e14 = 10,627). The values obtained as a result of covariance had a statistically significant contribution to the model. After these processes, the model met the good fit coefficient threshold values (Figure 3).



Figure 3. Model Reflection after Modification

Model good fit values are presented in table 2 [X2 (186): 595,828, p <.01; $\chi 2$ / df: 1,850; SRMR: ,033; RMSEA: ,064; NNFI: ,923; IFI: ,935; CFI: ,934; GFI: ,839; AGFI: ,796]. 
Table 2. Model Fit Coefficients

\begin{tabular}{|c|c|c|c|c|c|}
\hline Fit & Initial & Modified & One Factor & Acceptable Model Fit & References \\
\hline \multirow[t]{2}{*}{ Index } & Model & Model & Model & Levels & \\
\hline & Values & Values & Values & & \\
\hline \multirow[t]{3}{*}{$x^{2}$} & 2338.806 & 595.828; & 2809.262 & Low $\chi^{2}$ value and & Hooper, Coughlan and \\
\hline & $; p=$ & $\mathrm{p}<.01$ & $\mathrm{p}=.000 ; \Delta \chi^{2}$ & $\mathrm{p}<.01 ; \mathrm{p}>.05$ & Mullen (2008) \\
\hline & .000 & & $=2213.434$ & & \\
\hline$\chi^{2} / \mathrm{df}$ & 5.041 & 1.850 & 6.041 & & Wheaton et al. (1977); \\
\hline \multirow[t]{2}{*}{ RMSE } & .139 & .064 & .156 & RMSEA < .05-Good & Hu and Bentler (1999) \\
\hline & & & & & Steiger (2007) \\
\hline \multirow[t]{4}{*}{ SRMR } & .681 & .033 & .725 & $.00 \leq S R M R \leq .05$ Good & Byrne (1998) \\
\hline & & & & $.05 \leq$ SRMR $\leq .10$ Acceptab & Diamantopoulos and \\
\hline & & & & & Siguaw (2000);Hu and \\
\hline & & & & $\mathrm{SRMR} \leq .08$ & Bentler (1999) \\
\hline \multirow[t]{3}{*}{ GFI } & .489 & .839 & 472 & $.95 \leq$ GFI $\leq 1$ Good & Tabachnick and Fidell \\
\hline & & & & $.90 \leq \mathrm{GFI} \leq .95$ & (2007);Miles and \\
\hline & & & & Acceptable & Shevlin (2007) \\
\hline \multirow[t]{3}{*}{ AGFI } & .419 & .796 & 400 & $.90 \leq \mathrm{AGFI} \leq 1.00$ Good & Tabachnick and Fidell \\
\hline & & & & $.85 \leq \mathrm{AGFI} \leq .90$ & $(2007)$ \\
\hline & & & & Acceptable & \\
\hline \multirow[t]{3}{*}{ CFI } & .616 & .934 & .519 & $.95 \leq \mathrm{CFI} \leq 1.00 \mathrm{Good}$ & Hu and Bentler (1999) \\
\hline & & & & $.90 \leq \mathrm{CFI} \leq .95$ & Schumacker and \\
\hline & & & & Acceptable & Lomax, 1996 \\
\hline IFI & .618 & .935 & .522 & $95 \leq \mathrm{IFI} \leq 1.00 \mathrm{Good}$ & Miles and Shevlin \\
\hline
\end{tabular}


Acceptable

$\begin{array}{lllll}\text { NNFI } & .589 & .923 & .487 & .97 \leq \text { NNFI } \leq 1 \text { Good } \quad \text { Hu and Bentler (1999); }\end{array}$

$$
\text { NNFI }>0.90 \text { Acceptable Fan, Thompson and }
$$

Wang (1999)

Bentler and Bonett

(1980)

\footnotetext{
Note: $x^{2}$ Discrepancy Chi Square; $x^{2} / \mathrm{df}$ (Chi Square/Degrees of Freedom); RMSEA (Root Mean Square of Error Approximation); SRMR (Standardized Root Mean Square Residual); GFI (Goodness of Fit Index); AGFI (Adjusted Goodness of Fit); CFI (Comparative Fit Index); IFI (Incremental Fit Index); NNFI (Non-Normed Fit Index) TLI (Tucker-Lewis Index)
}

After the modifications, the model met the good fit criteria. However, the impact of the clarity of measurement tools for participants on the results of the analysis needs to be explored. Therefore, as suggested in the literature, the research model was compared with a single-factor structure. The single factor structure is performed to reveal the existence of common method biases (MacKenzie \& Podsakoff, 2012). In this method, items of all scales are collected under a single structure. The significant difference between the one-factor structure obtained and the model structure analyzed theoretically is revealed in this method. The variance between the Chi-Square $\left(\chi^{2}\right)$ values of the results obtained provides evidence about the existence of the common method of bias (MacKenzie \& Podsakoff, 2012). The data obtained according to this method proved that there is no common method bias in the measurement tools $\left(\Delta \chi^{2}\right.$ $=2213,434 ; \mathrm{p}<.01)$.

When the model good fit values and analysis findings were compared, it was found that the AGFI and GFI values were below the threshold value. In the literature, it is suggested that these two values are sensitive to the sample size, therefore CFI, IFI, SRMR, and RMSEA values should be taken into consideration as a criterion (Hu \& Bentler, 1999; Kline, 2016). Especially in model analysis, it is suggested that these values should be above the threshold value (Hu \& Bentler, 1999). In the literature, it is argued that if GFI and AGFI are below the threshold value, other values are acceptable (Brown, 2015; Hu \& Bentler, 1999). The reason for this is that these values are measured as low especially in small samples depending on the number of samples. If the CFI, 
IFI, and TLI values are above the threshold values, other model good fit values can be accepted (Brown, 2015). As a result, the model was found to meet good fit criteria.

Boreout scale consists of 11 and the DASS-21 scale consists of 21 items. The factor loadings of the scale constituting the scale are suggested to be 0.300 and above in the literature (Tabachnick \& Fidell, 2007). Analysis findings showed that factor loads varied between $0.600-0.900$. These findings demonstrated that the items could measure the scale to which they depended without error. On the other hand, the average variance extracted (AVE) values were determined as follows: boreout $=0,489$; depression $=0.568$; anxiety $=0,521$ and stress $=0,679$. The AVE value for Boreout was measured under 0.5. However, as suggested in the literature, this value is acceptable since the composite reliability (CR) value is more than 0.7 (Fornell \& Larcker, 1981; Hair et al., 2016; Nunnally, 1976; Kline, 2005; Kline, 2016; Hu \& Bentler, 1999). In light of these results, the findings met the convergent validity criteria.

Table 3. Convergent and Discriminant Validity of the Model

\begin{tabular}{|c|c|c|c|c|c|c|c|c|c|}
\hline & a & CR & AVE & MSV & $\operatorname{MaxR}(\mathrm{H})$ & Stress & Depression & Anxiety & Boreout \\
\hline Stress & .938 & .937 & .679 & .672 & .943 & $.824^{a}$ & - & - & - \\
\hline Depression & .901 & .901 & .568 & .533 & .911 & $.730^{*}$ & $.754^{\mathrm{a}}$ & - & - \\
\hline Anxiety & .890 & .883 & .521 & .672 & .891 & $.820^{*}$ & $.673^{*}$ & $.721^{\mathrm{a}}$ & - \\
\hline Boreout & .842 & .870 & .489 & .341 & .871 & $.419^{*}$ & $.584^{*}$ & $.366^{\mathrm{a}}$ & - \\
\hline Mean & - & - & - & - & - & 1,06 & 1,10 & .668 & 2,72 \\
\hline Std. & - & - & - & - & - & .858 & .773 & .738 & 1,27 \\
\hline
\end{tabular}

Note: $\mathrm{\alpha}=$ Cronbach's alpha; $\mathrm{CR}=$ composite reliability; $\mathrm{AVE}=$ average variance extracted; $\mathrm{MSV}=$ maximum shared variance; $\operatorname{MaxR}(\mathrm{H})=$ maximum reliability; a Square root of AVE value; * Pearson Correlation; AVE is significant over the 0.50 level, the acceptable value of CR is 0.7 and above; DASS-21 Cornbach $\alpha=0.953$

In the context of discriminant validity, a value of less than 0.85 is evidence of the existence of discriminant validity between the two scales (Fornell \& Larcker, 1981). The model met the threshold values recommended in the literature. The convergent and discriminant (divergent) validity method is applied to confirm the measurementspecific distinctiveness of measurement tools after modification (Kline, 2016). In this 
method, the indifference of the items or measurement tools are measured (Nunnally, 1976). Recommended values for measurement are composite reliability (CR), average variance extracted (AVE), maximum shared variance (MSV), maximum reliability $(\operatorname{Max} R(\mathrm{H}))$, and Pearson Correlation. AVE values should be higher than 0.5 and $\mathrm{CR}$ values should be higher than 0.70 (Hu \& Bentler, 1999; Fornell \& Larcker, 1981; Hair et al., 2016). Also, AVE values should be less than its square root (Fornell \& Larcker, 1981). The square root of AVE values were determined as stress $=0,824$, depresion=0,754, anxiety=0,721 and boreout=0,699. According to the results, the research scales met the convergent and discriminant validity. The composite reliability values of the factors were measured as stress $=0,937$, depresion $=0,901$, anxiety $=0,883$ and boreout $=0,870$. Cronbach's a values with internal consistency coefficients were also calculated and measured as stress $=0,938$, depresion $=0,901$, anxiety $=0,890$ and boreout $=0,842$. Discriminant validity is acceptable if $C R$ values are higher than 0.7 (Fornell \& Larcker, 1981). Although the AVE value of the "boreout" variable is 0.489 (rounded to 0.50 ), it meets all the criteria as suggested in the literature. In light of these results, depression, stress, anxiety, and boreout were found to be valid and reliable. In addition, the mean scores and standard deviation data of the scales were determined as follows: stress: $1,06( \pm .858)$, depression $1,10( \pm .773)$, anxiety $.668( \pm .738)$, boreout 2,72 $( \pm 1,27)$.

\subsection{Direct Effects}

The model fit coefficients of the model examined to test direct effects were given in Table 4. The effects of the exogenous variable of boreout on the endogenous variables of depression $(\mathrm{t}=6,623, \mathrm{p}<.01)$, anxiety $(\mathrm{t}=4,108, \mathrm{p}<.01)$ and stress $(\mathrm{t}=$ $5,218, p<.01)$ were found to be significant in this model. The direct effects were detected using the Bootstrap method via the AMOS software (Byrne, 2013). Bootstrapping is a method that provides an estimation of the current sample with a larger data set (Sacchi, 1998). The bootstrap method is recommended because it is a reliable method in the calculation of indirect and direct effects analyses (Hair et al., 2016, 2006).

The direct effect of boreout on DASS-21 subscales was found to be significant (Boreout $\rightarrow$ Depression; Boreout $\rightarrow$ Anxiety; Boreout $\rightarrow$ Stress. According to the findings 
obtained by Structural Equation Model (SEM) analysis with AMOS, boreout was positively associated with depression $(\mathrm{H} 1: \beta=0,584 \mathrm{t}=6,623 ; \mathrm{p}<0,01)$, anxiety $(\mathrm{H} 2$ : $\beta=0,366 ; t=4,108 ; p<0,01)$ and stress $(H 3: \beta=0,419 ; t=5,218 ; p<0,01)$. Thus, hypotheses $\mathrm{H} 1, \mathrm{H} 2, \mathrm{H} 3$ for the direct effects were supported. The results of the research demonstrated that when boreout increased, depression, anxiety, and stress levels also increased.

Table 4. SEM Analysis Findings

\begin{tabular}{ccccccc}
\hline Boreout & Lower & Upper Bounds & $\mathrm{T}$ & $\boldsymbol{\beta}$ & $\mathbf{p}$ & Direct Effects \\
& Bounds & & $(1860)$ & & & \\
\hline Depression & .416 & .715 & 6.623 & .584 & $.001^{* *}$ & Positive \\
Anxiety & .220 & .516 & 4.108 & .366 & $.001^{* *}$ & Positive \\
Stress & .258 & .569 & 5.218 & .419 & $.001^{* *}$ & Positive
\end{tabular}

Note: *significant at 0.1 (two tailed); ${ }^{* *} \mathrm{p}$ is significant at 0.05 (two tailed) ${ }^{* * *} \mathrm{p}$ is significant at 0.01 (two tailed); The confidence interval values for direct effects were calculated by bootstrap with $\mathrm{N}=1860$. If zero $(0)$ does not match within the confidence interval values, the direct effect is significant; $\beta$, Standard Beta; $t$ : Critical ratio

\subsection{Qualitative Findings}

\subsubsection{Job Meaningless}

Participants were asked whether their job was meaningless. According to the obtained results, $40,29 \%$ of the participants find their job as meaningless due to the manager actions, of the $30,63 \%$ reasons based on employees, of the $9,12 \%$ reasons based on working conditions (Table 5). 
Table 5. The Coding Analysis Results of Job Meaningless

\begin{tabular}{|c|c|c|c|}
\hline \multicolumn{2}{|c|}{ What makes your job meaningless? } & \multirow[t]{2}{*}{$\mathbf{f}$} & \multirow[t]{2}{*}{$\%$} \\
\hline Dimension & Subdimension & & \\
\hline \multirow[t]{6}{*}{ Problems arising from managers } & Be unappreciated & 11 & 5.91 \\
\hline & Work overload & 11 & 5.91 \\
\hline & Unfair task distribution & 10 & 5.37 \\
\hline & Assigning inexpedient tasks & 9 & 4.83 \\
\hline & Mobbing & 13 & 6.98 \\
\hline & Obstruction of job & 21 & 11.29 \\
\hline \multirow[t]{4}{*}{ Problems arising from employees } & Unrecompensed for effort or work & 28 & 15.05 \\
\hline & Finding job meaningless & 19 & 10.21 \\
\hline & Finding job simple & 7 & 3.76 \\
\hline & Necessity & 3 & 1.61 \\
\hline Problems arising from working & Time & 5 & 2.68 \\
\hline \multirow[t]{2}{*}{ conditions } & Customers & 3 & 1.61 \\
\hline & Other & 9 & 4.83 \\
\hline $\begin{array}{l}\text { Those who do not want to } \\
\text { comment. }\end{array}$ & & 37 & 19.89 \\
\hline
\end{tabular}

Participants can think through experience that their work is meaningless: "My job is meaningless because the service sector is an unlimited sector and it will never ends." "Missing and time-consuming task types that have nothing to do with job description" "What I don't know why and things that I can't make sense are meaningless to me". Participants stated that when they make a comparison between their competencies, they see the work as simple and cause them to see it as meaningless: "Simplify the job, not being aware of the seriousness of the work". Participants highlighted that performing the job due to their financial conditions and needs was an important factor in job meaningless. 


\subsubsection{Job Boredom}

The participants were asked whether the job was bored them. According to the results, $23,65 \%$ of the participants find their job as boring due to the manager actions, of the $35,50 \%$ reasons based on employees, of the $25,25 \%$ reasons based on working conditions (Table 6). According to the results of the interview, the participants stated that the working conditions were the factors of frustration of self-fulfillment, carrier development, bureaucracy, workplace climate, customer-related problems and time constraints.

Table 6. The Coding Analysis Results of Job Boredom

\begin{tabular}{|c|c|c|c|}
\hline \multicolumn{2}{|l|}{ What makes your job boring? } & \multirow[t]{2}{*}{$\mathbf{f}$} & \multirow[t]{2}{*}{$\%$} \\
\hline Dimension & Subdimension & & \\
\hline Problems arising from working & Frustration of self-fulfillment/ Works & 8 & 4.3 \\
\hline \multirow[t]{7}{*}{ conditions } & that are not suitable for carrier & & \\
\hline & development & & \\
\hline & Bureaucracy & 11 & 5.91 \\
\hline & Environmental factors/Workplace & 7 & 3.76 \\
\hline & climate & & \\
\hline & Customer-related problems & 9 & 4.83 \\
\hline & Time & 12 & 6.45 \\
\hline \multirow[t]{3}{*}{ Problems arising from employees } & Job dislike & 3 & 1.62 \\
\hline & Unworthy job & 12 & 6.45 \\
\hline & Monotonous job & 51 & 27.43 \\
\hline \multirow[t]{5}{*}{ Problems arising from managers } & Psychological pressure & 3 & 1.62 \\
\hline & Be unappreciated & 4 & 2.15 \\
\hline & Work overload & 7 & 3.76 \\
\hline & Be ignored & 3 & 1.61 \\
\hline & Problems based on managers & 27 & 14.51 \\
\hline Those who do not want to comment & & 29 & 15.6 \\
\hline
\end{tabular}


Participants stated that job boredom was caused by the actions of the managers. The executive actions, which confine the area of individual freedom, burn out the individual psychologically and spiritually, and reduce the psychological power by overburdening the physical power cause job boredom. Participants expressed that they were subjected to the factors caused job-boredom as psychological pressure (“...working under pressure, to be hurried."), being unappreciated ("I have passed money and spiritual dimension, they do not even thank."), work overload (“...unnecessary workload”) and being ignored by the managers ("This is my chair, I'm sitting idle all day."). In addition they stated due to the characteristics of the managers affected their job and achieving goals it was caused job-boredom: "Uneducated and uninformed business owners" "That the person who gave the task does not know whether the work is my responsibility or not despite this he calls me to account".

\subsubsection{Stress Factors in the Workplace}

The participants were asked the most important factor that caused them to have been stressed with their job. According to the results, 38,7\% of the participants stressed due to the manager actions, of the $23,13 \%$ reasons based on employees, of the $38,17 \%$ reasons based on working conditions (Table 7). 
Table 7. The Coding Analysis Results of Stress Factors in the Workplace

\begin{tabular}{|c|c|c|c|}
\hline \multicolumn{2}{|c|}{$\begin{array}{l}\text { What is the most important factor that causes you to be } \\
\text { stressed about your job? }\end{array}$} & \multirow[t]{2}{*}{$\mathrm{f}$} & \multirow[t]{2}{*}{$\%$} \\
\hline Dimension & Subdimension & & \\
\hline Working & Relations with colleagues and restlessness & 18 & 9.68 \\
\hline \multirow[t]{4}{*}{ conditions } & Work overload & 16 & 8.60 \\
\hline & Personal rights & 14 & 7.52 \\
\hline & Liability/risk & 16 & 8.6 \\
\hline & The difficulty level of the job & 7 & 3.77 \\
\hline \multirow{3}{*}{$\begin{array}{l}\text { Based on } \\
\text { employees }\end{array}$} & Professional inadequacy (phobias, failure, & 19 & 10.23 \\
\hline & panic) & & \\
\hline & Relations with the customers & 24 & 12.9 \\
\hline Based on & Management problems & 20 & 10.75 \\
\hline \multirow[t]{3}{*}{ managers } & Psychological pressure/mobbing & 8 & 4.30 \\
\hline & Inequality in task distribution & 4 & 2.15 \\
\hline & time management stress & 40 & 21.5 \\
\hline
\end{tabular}

Participants expressed the stress they experienced in the workplace with the same headings as the boreout state. One of the most crucial factors was stated as working conditions and workplace climate. While the workplace climate was stated as an important stress factor by the participants, the working conditions were perceived as the same with this factor. Therefore it was examined under the same heading. Stress factors reported by the participants were expressed as follows: Relations with colleagues and restlessness ("to manage the situation in order to carry out the relationship between the two people", "work with stressed colleagues" "personalization of events of colleagues, ego"), work overload ("when work intensively high, complaints can occur to my superior", "Apart from our work, we have a problem of time in our main business due to the jobs coming in the form of a drudgery"), personal rights ("Working conditions, the fact that the annual permits 
have never been used is a situation I think every day"), liability/risk ("Being at risk"; "Being about money, not tolerate any mistakes") and the difficulty level of the job (“..lack of solution” “..complexities”).

One of the main reasons for the stress experienced in the workplace is the issues arising from the actions of the managers. Participants stated that managers were not aware of their responsibilities, they were unstable and inconsistent, they could not do the work properly, they kept their egos at the forefront: "Highly ignorant executives, they know it all!", "Different and personal caprices come to the forefront". The participants stated that they experienced stress when they were subjected to psychological pressure and mobbing in the workplace: "supervisor pressure" "they always call me to account", "mobbing". According to the participants, one of the actions of the managers triggering the stress is the unfairness of the managers. They stated that when they did not distribute tasks and responsibilities fairly, they got a significant level of stress with their work: "Disordered working system in the workplace and the pressure on me as a result of the demand of the works that do not belong to my field". Chambers employees also revaled that stress caused the time management not to be performed correctly by the managers: "Our business depends on time." "Finish the job in time, deadline pressure!".

\subsubsection{Wipeout Stress in the Workplace}

The participants were asked how to get rid of stress in the workplace. According to the results $62,89 \%$ of the employees prefer keeping away from stress, $9,68 \%$ accept the stress, of the $27,43 \%$ are coping with stress in the workplace (Table 8 ). 
Table 8. The Coding Analysis Results of Coping With Stress in The Workplace

\begin{tabular}{lllc}
\hline What do you do to get rid of stress at work? & f & \% \\
\hline Dimension & Subdimension & & \\
\hline Keep away from stress & Strengthen communication with colleagues / talk & 15 & 8.06 \\
& Short break to work/take a break & 38 & 20.43 \\
& Listening to music-hobbies-sports activities & 37 & 19.89 \\
& Smoking- coffee-tea & 24 & 12.9 \\
& Social media & 3 & 1.61 \\
\hline Acceptance of stress & - & 18 & 9.68 \\
\hline Cope with stress & Self motivation & 29 & 15.6 \\
& Being fortitude & 10 & 5.38 \\
\hline & Try not to see problems & 12 & 6.45 \\
\hline
\end{tabular}

Participants suggested keeping away from stress as the most effective method to wipe out stress. They stated as a method of keeping away from stress that they strengthened communication with colleagues: "I contact my colleagues who are more experienced than me.", "I visit other services and offices". Participants believe that a short break to work ("I rest for a short while." "I take a break to get some fresh air."), music-hobbies-sports activities ("I listen to classical music, air the room, walk around, eat and drink."), smoking-coffee-tea habits ("I give short breaks such as coffee, tea break.") concerning with social media ("I try to follow the news and social media.") can to wipe out stress in the workplace. On the other hand, the participants believe that the acceptance of stress, albeit to a lesser extent, wipe out stress: "Getting rid of stress is hard.", "...there is nothing to do". These participants think that stress can be wipe out by accepting stress instead of struggling.

Participants prefer to cope with stress as another method to wipe out: Self motivation ("I try to make my work as stress-free and enjoyable as possible" "I am gonna be alone with myself and empty my mind."), being fortitude ("Focus on my work, I try to do the best.") and trying not to see problems ("I try not to deal with those 
who have understanding problems, as much as I can."; "I minimize communication with negative people.").

\subsubsection{Being Happy While Stressed}

The participants were asked how to be happy while stressed in the workplace. According to the results 56,46\% of the employees prefer keeping away from stress, $11,29 \%$ accept the stress, of the $32,25 \%$ are coping with stress to be happy in the workplace (Table 9).

Table 9. The Coding Analysis Results of Coping with Stress in the Workplace

\begin{tabular}{llcc}
\hline What do you do to be happy when you're stressed? & f & $\%$ \\
\hline Dimension & Subdimension & & \\
\hline Inactivity & & 21 & 11.29 \\
\hline Self motivation & Focus on job & 13 & 6.99 \\
& Spiritual satisfaction & 13 & 6.99 \\
& Positive sense & 34 & 18.28 \\
& & 17 & 9.14 \\
\hline Taking a rest and break & Take a break & 44 & 23.65 \\
& Listening to music-hobbies- & & \\
& sports activities & 23 & 12.37 \\
\hline Eating, drinking and & Communication/talk & & \\
\hline smoking & & 21 & \\
\hline
\end{tabular}

$11,29 \%$ of the participants who participated in the research argued that being happy was possible by accepting the stress:" This is the most difficult. I cannot do anything. I have no way." "What can you do? I am alone with faces like court walls and have headaches.". $32,26 \%$ of the participants think that the self-motivation of the employee can turn the stressful state to the advantage of happiness: Focus on job ["I finish my work then go out early"; "I focus on finishing the job, then I reward myself (tea, coffee etc.)]", spiritual satisfaction ("I pray the God"; "I talk to my family.") and 
positive sense ("positive thinking is enough to make me happy "; "I think about the future and say to myself that be patient!").

Of the $45,16 \%$ participants become happy when they take a break ("I get away from my place, I'm going to throw the current gloom off me."), perform musichobbies-sports activities ("I listen to music, I also do sports outside after hours." "I try to do an activity that I love.") and communicate with people ("I try to chat with people while I am doing my job" "I would like to joke and talk"). 11,29\% of the participants are able to cope with stress through coffee, smoking and eating habits: "I go out to smoke.", "I get a bite to eat".

\section{DISCUSSION}

The effects of boreout on depression, anxiety and stress of the employees affiliated to chambers of commerce were examined in this study. Boreout syndrome causes the employees to perceive their work as meaningless in their workplace, their belief that they do not have career opportunities, and that they have significant problems focusing on work. According to the researches on this subject, employee innovative work behavior was associated with the crisis of growth and meaning negatively (Stock, 2015). According to another finding, a negative relationship was found between the crisis of meaning and growth at work, job boredom and customeroriented behavior. According to the quantitative results, it was found that boreout was positively associated with depression (H1), anxiety (H2) and stress (H3). Previous studies clearly revealed the negative workplace effects of boreout (Stock, 2015; Stock, 2016; Moeller et al., 2018), depression (Swindle, Kroenke \& Braun, 2001; Evans-Lacko et al., 2016; Halpern, Khan \& Rentz, 2001), anxiety (Lovibond \& Lovibond, 1995; Clercq, Haq \& Azeem, 2018; Olive \& Cangemi, 2015; Zellars, 2007) and stress (Statt, 2004; Lovibond \& Lovibond, 1995; Fairbrother \& Warn, 2003; Buchanan \& Huczynski, 2004; LeFevre, Matheny, \& Kolt, 2003; Sparks \& Cooper, 1999; Siegrist, 1998; Tett \& Meyer, 1993; Sullivan \& Bhagat, 1992; Williams \& Hazer, 1986; Leong et al., 1996; DeFrank \& Ivancevich, 1998) on employees (H1, H2, H3). However, there was no study directly related to the hypothesis results.

Findings revealed the positive association between boreout, depression, anxiety and stress. Qualitative findings confirmed the positive association between stress and 
boreout. This finding proves the great impact of boreout on the chambers employees. Furthermore, the qualitative research findings showed that the meaningless of job and the job boredom, which are two main factors of the boreout syndrome, significantly affect the employees in comparison to the other sub-dimensions (opportunities for personal growth and development). In addition, the coding findings confirmed the three-dimensional structure of the boreout scale (Table 10). Stock (2015) revaled that the crisis of growth dimesion (the third dimension of the boreout) involved "opportunities for personal growth and development", "the feeling of achievement", "the possibility of independent thought and action", "learning new things". The qualitative analysis findings showed that "the crisis of growth" dimension appeared under the "boredom" dimension and "working conditions" sub-dimension. According to the interview responses it was determined that participants did not link carrier development with "opportunities for personal growth and development". Especially career development was emphasized linked to working environment and conditions in stress factors.

It is noteworthy that close to $20 \%$ of participants did not want to comment on these two factors. Participants who avoided commenting on these questions responded questions on stress. This shows the effect of mobbing. The problems caused by the managers were mostly revealed by the participants. This finding indicates that the meaning of the job wipes out when employees perform tasks under the negative influence of the manager. The employees associate job boredom with themselves. The results of the research revealed that the employees were mostly keeping away from stress to wipe out the stress and be happy. In addition, the results showed that the stress of time management significantly affected the work life. 
Table 10. The Coding Analysis Comparison Table

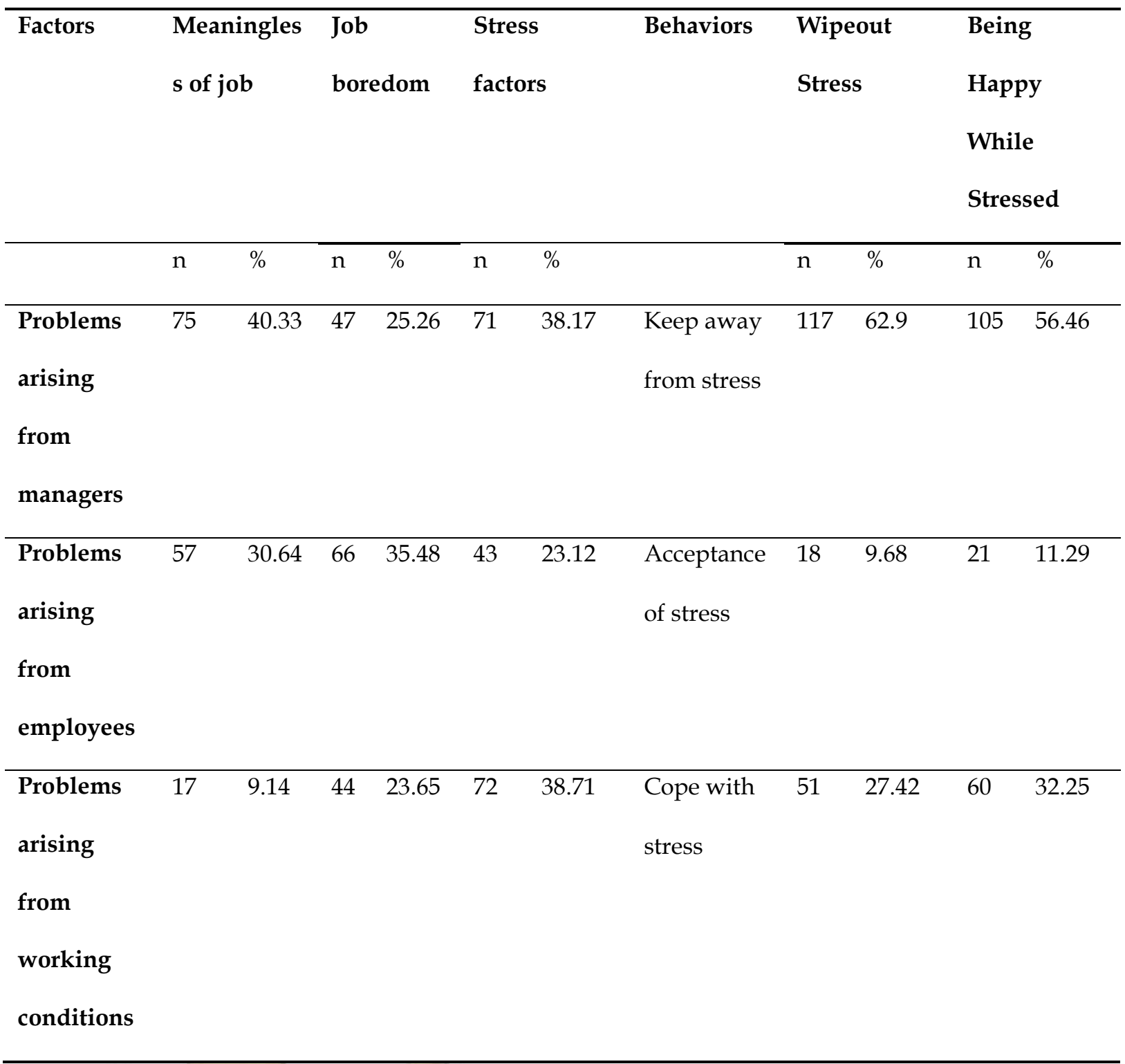

\section{LIMITATIONS AND RECOMMENDATIONS FOR FUTURE STUDIES}

This study is a research that has not been studied before, which investigated the association between boreout, stress, depression and anxiety and their negative effects on employees. However, there were some limitations for the study. The fact that the study limited with employees recruited from chambers of commerce in Turkey sample affected the generalizability of the results (Converse \& Presser, 1986). Boreout, stress, depression and anxiety scales involve negative items and can create inconsistency in terms of the responses. Indeed, some participants did not accept to answer jobboredom and job meaningless questions. Furthermore boreout can be explained by 
following three factors: managers, employees and workplace conditions. Stress is perceived by the employees as three main effects in terms of keeping away, accepting and struggling. It is thought that this new knowledge will make crucial contributions for future studies.

The negative psychological states that boreout reveals in the workplace can affect its organizational climate, employee satisfaction and commitment, and leaderemployee interaction. This can negatively affect organizational performance, service innovation behavior, and intrapreneurship. Due to this reason, it is recommended to develop a strategy to eliminate the negative effects of boreout via human resources management in organizations. It is also recommended that group work, vocational training be performed in the context of boreout, stress and depression management. Considering the importance of working conditions in stress factors, it is important to review the working conditions of the employees for being away from stress. It should be taken into consideration by the managers that employees have private lives. In order to eliminate the stress of the employees, they generally prefer to keep away from the workplace, it requires the establishment of some areas of freedom in the workplaces. It should be kept in mind that work place needs to be given importance to human element for increasing productivity and sustainable competition. In particular, managers should be given training on stress, depression and anxiety.

Conducting qualitative studies on boreout with various samples will make important contributions to the literature. It is recommended to examine psychological empowerment and the association between successful aging, burn out in the workplace and the study variables (Spreitzer, 1995). Furthermore, the boreout scale can be redeveloped by evaluating with stress factors. 


\section{REFERENCES}

Bailey, C., \& Madden, A. (2016). What makes work meaningful-or meaningless? MIT Sloan management review, 57(4), 1-17.

Bakker, A. B., M. van Veldhoven, \& D. Xanthopoulou. (2010). Beyond the demand-control model. Thriving on high job demands and resources. Journal of Personnel Psychology. 9 (1), 3-16.

Bentler P M \& Bonett D G. (1980). Significance tests and goodness of lit in the analysis of covariance structures. Psychol. Bull., 88, 588-606.

Blau, P. (1964). Exchange and power in social life. New York, NY: Wiley \& Sons.

Brown, T. A. (2015). Confirmatory factor analysis for applied research. Guilford Publications.

Buchanan, D., \& Huczynski, A. (2004). Organisational Behaviour: An Introductory Text, 5th ed. Harlow: Pearson Education Ltd.

Burke, R.J. (1988). Sources of managerial and professional stress in large organisations. in Cooper, C.L. and Payne, R. (Eds), Causes, Coping and Consequences of Stress at Work, (pp. 77-112) John Wiley \& Sons, Chicester.

Byrne, B.M. (1998). Structural Equation Modeling with LISREL, PRELIS and SIMPLIS: Basic Concepts, Applications and Programming. Mahwah, New Jersey: Lawrence Erlbaum Associates.

Byrne, B. M. (2013). Structural equation modeling with amos: basic concepts, applications, and programming (Second Edition). Taylor \& Francis.

Cangialosi, N., Odoardi, C., \& Battistelli, A. (2020). Learning Climate and Innovative Work Behavior, the Mediating Role of the Learning Potential of the Workplace. Vocations and Learning, 1-18.

Clercq, D.D., Haq, I.U., \& Azeem, M.U. (2018). Self-efficacy to spur job performance: Roles of job-related anxiety and perceived workplace incivility. Management Decision, 56(4), 891-907.

Converse, J. M., \& Presser, S. (1986), Survey questions: Handcrafting the standardized questionnaire,

Newbury Park, CA: Sage Publications.

Carlopio, J., Andrewartha, G., \& Armstrong, H. (1997). Developing Management Skills in Australia. South Melbourne: Longman.

Davies, P. (2000). Contributions from Qualitative Research. In H. T. Davies, M. N. Sandra, \& P. Smith (Eds). What works? Evidence-based Policy and Practice in Public Services (pp. 291- 316), Bristol, UK: Policy Press.

DeFrank, R.S. \& Ivancevich, J.M. (1998). Stress on the job: an executive update. Academy of Management Executive, 12(3), 55-66.

Diamantopoulos, A. \& Siguaw, J.A. (2000). Introducing LISREL. London: Sage Publications. 
Dutton, J. E., L. M. Roberts, \& J. Bednar. (2010). Pathways for positive identity construction at work: Four types of positive identity and the building of social resources. Academy of Management Review, 35 (2), 265-93.

Embriaco N, Papazian L, Kentish-Barnes N, Pochard F, \& Azoulay E. (2007). Burnout syndrome among critical care healthcare workers. Current Opinion in Critical Care, 13(5), 482-488.

Evans-Lacko, S.E., Koeser, L., Knapp, M., Longhitano, C., Zohar, J., \& Kuhn, K. (2016). Evaluating the economic impact of screening and treatment for depression in the workplace. European Neuropsychopharmacology, 26, 1004-1013.

Fairbrother, K., \& Warn, J. (2003). Workplace dimensions, stress and job satisfaction. Journal of Managerial Psychology, 18(1), 8-21.

Fan, X., Thompson, B., \& Wang, L. (1999). Effects of Sample Size, Estimation Methods, and Model Specification on Structural Equation Modeling Fit Indexes. Structural Equation Modeling, 6 (1), 56-83.

Field, A.(2005). Discovering Statistics Using SPSS, 2nd edn, London: SAGE.

Fisher, C. D. (1998). Effects of external and internal interruptions on boredom at work: Two studies. Journal of Organizational Behavior, 19 (5), 503-22.

Fornell, C. \& Larcker, D. F. (1981). Evaluating structural equation models with unobservable variables and measurement error. Journal of marketing research, 39-50.

Foster, K., Roche, M., Giandinoto, J. A., \& Furness, T. (2020). Workplace stressors, psychological wellbeing, resilience, and caring behaviours of mental health nurses: A descriptive correlational study. International journal of mental health nursing, 29(1), 56-68.

Greene, J. C., Caracelli, V. J., Graham, W. F. (1989). Toward a conceptual framework for mixedmethod evaluation designs. Educational Evaluation and Policy Analysis, 11(3), 255-274.

Hair Jr, J. F., Hult, G. T. M., Ringle, C., \& Sarstedt, M. (2016). A primer on partial least squares structural equation modeling (PLS-SEM). Sage Publications.

Halpern, M., Khan, Z., \& Rentz, A. (2001), The interaction of depression and smoking on workplace productivity, in Irina Farquhar, Kent Summers, Alan Sorkin (ed.) Investing in Health: The Social and Economic Benefits of Health Care Innovation (Research in Human Capital and Development, Volume 14), (pp.377 - 387). Emerald Group Publishing Limited.

Hu, L. \& Bentler, P.M. (1999). Cutoff Criteria for Fit Indexes in Covariance Structure Analysis: Conventional Criteria Versus New Alternatives. Structural Equation Modeling: A Multidisciplinary Journal, 6(1), 1-55.

Gefen, D., Straub, D., \& Boudreau, M.-C. (2000). Structural Equation Modeling and Regression: Guidelines for Research Practice. Communications of the Association for Information Systems, 4(1), 2-77. 
Hooper, D., Coughlan, J., \& Mullen, M. (2008). Structural equation modelling: guidelines for determining model fit. Electronic Journal of Business Research Methods, 6(1), 53-60.

Jones, G., Moore, K. A., Porter, J., \& Morgan, D. (2018). Why does the psychological contract matter? Implications for leadership practice, workplace stress and anxiety. In Stress and anxiety: Theories and realities (pp. 33-44). Logos Verlag.

Karadal, H., Abubakar, A.M., \& Erdem, A.T. (2018), Boreout, Kariyer Uyumluluğu ve Aile-İşs Zenginleştirme Etkileşimi: Selçuk Üniversitesi Örneği. Sosyal Ekonomik Araştırmalar Dergisi, 18(35).

Kline, R.B. (2005). Principles and Practice of Structural Equation Modeling (2nd Edition ed.). New York: The Guilford Press.

Kline R. B. (2016). Principles and Practices of Structural Equation Modeling (4th Edn). New York, NY: The Guilford Press.

LeFevre, M., Matheny, J., \& Kolt, G.S. (2003). Eustress, distress and interpretation in occupational stress. Journal of Management Psychology, 18(7), 726-44.

Leiter, MP, Bakker, AB, \& Maslach C. (2014). Burnout at work: a psychological perspective. New York: Psychol Press.

Leong, C.S., Furnham, A., Cary, L., \& Cooper, C.L. (1996). The moderating effect of organizational commitment on the occupational stress outcome relationship. Human Relations, 49(10), 1345-1363.

Løkke, A.K. \& Madsen, H. (2014). Public sector managers and work stress. International Journal of Workplace Health Management, 7(2), 105-120.

Lovibond, P. F. \& Lovibond, S. H. (1995). The structure of negative emotional states: Comparison of the Depression Anxiety Stress Scales (DASS) with the beck depression and anxiety inventories.

Behaviour Research and Therapy, 33 (3), 335-343.

MacKenzie, S.B. \& Podsakoff, P.M. (2012). Common method bias in marketing: Causes, mechanisms, and procedural remedies. Journal of Retailing, 88, 4, 542-555.

Miles, M.B. \& Huberman, A.M. (1994). Qualitative Data Analysis (2nd ed.). London: Sage.

Miles, J. \& Shevlin, M. (2007). A time and a place for incremental fit indices. Personality and Individual Differences, 42(5), 869-874.

Moeller, J., Ivcevic, Z., White, AE., Menges, J.I., \& Brackett, MA. (2018). Highly engaged but burned out: intra-individual profiles in the US workforce. Career Development International, 23 (1), 86-105.

Naumann, E. (1993). Antecedents and consequences of satisfaction and commitment among expatriate managers. Group \& Organization Management, 18(2), 153-187. 
Nelson, D.L. \& Burke, R.J. (2000). Women executives: health, stress, and success. Academy of Management Executive, 14(2), 107-121.

Nunnally, J. C. (1976). Psychometric theory (2nd ed). New York: McGraw-Hill.

Olive, K. \& Cangemi, J. (2015). Workplace bullies: why they are successful and what can be done about it?. Organization Development Journal, 33(2), 19-31.

Onwuegbuzie, A. J. \& Leech, N. L. (2004). Enhancing the Interpretation of "Significant" Findings: The Role of Mixed Methods Research. The Qualitative Report, 9(4), 770-792.

Özsungur, F. (2020). The Effects of Mobbing in the Workplace on Service Innovation Performance: The Mediating Role of Boreout. İşletme Araştırmaları Dergisi- Journal of Business Research-Turk, 12(1), 28-42.

Roberts, A.M., Gallagher, K.C., Daro, A.M., Iruka, I.U. \& Sarver, S.L. (2019). Workforce well-being: Personal and workplace contributions to early educators' depression across settings. Journal of Applied Developmental Psychology, 61, 4-12.

Sacchi, M.D. (1998). A bootstrap procedure for high-resolution velocity analysis. Geophysics, 63(5), 17161725 .

Schumacker, R.E. \& Lomax, R.G. (1996). A Beginner's Guide to Structural Equation Modeling. Mahwah. New Jersey: Lawrence Erlbaum Associates, Publishers.

Santiago, J. M. C., Vega, A. V., \& Alvarado, R. A. V. (2020). The Predictors of Job Burnout on Job Boredom in a sample of workers in the banking industry of Puerto Ricol/Predictores del agotamiento laboral por aburrimiento laboral en una muestra de trabajadores de la industria bancaria de Puerto Rico/Previsores de burnout profissional no tedio no emprego em uma amostra de trabalhadores do setor bancario de Porto Rico. Informes Psicologicos, 20(1), 167-182.

Schnell, T. (2010). Existential indifference: Another quality of meaning in life. Journal of Humanistic Psychology, 50 (3), 351-73.

Siegrist, J. (1998). Adverse health effects of effort-reward imbalance at work; theory, empirical support and implications for prevention. In Cooper, C.L. (Ed.), Theories of Organizational Stress, (pp. 153-69). Oxford University Press, Oxford.

Sparks, K. \& Cooper, C.L. (1999). Occupational differences in the work-strain relationship: towards the use of situation specific models. Journal of Occupational and Organisational Psychology, 72, 219-29.

Spradley, J. P. (1980). Participant Observation. Orlando, FL: Harcourt, Inc.

Spreitzer, G.M. (1995). Psychological empowerment in the workplace: dimensions, measurement, and validation. Academy of Management Journal, 38 (5), 1442-1465.

Statt, D.A. (2004), Psychology and the World of Work. Palgrave Macmillan, Basingstoke. 
Stevens, J.P. (1992). Applied Multivariate Statistics for the Social Sciences (2 nd edition). Hillsdale, NJ: Erlbaum.

Steiger, J.H. (2007). Understanding the limitations of global fit assessment in structural equation modeling. Personality and Individual Differences, 42(5), 893-898.

Stock, R. M. (2015). Is boreout a threat to frontline employees' innovative work behavior? Journal of

Product Innovation Management, 32(4), 574-592. DOI: 10.1111/jpim.12239.

Stock, RM. (2016). Understanding the relationship between frontline employee boreout and customer orientation. Journal of Business Research, 69, 4259-4268.

Strauss, A. \& Corbin, J. (1990). Basics of Qualitative Research: Grounded Theory Procedures and Techniques. New Delhi: SAGE Publications.

Sullivan, S.E. \& Bhagat, R.S. (1992). Organizational stress, job satisfaction and job performance: where do we go from here? Journal of Management, 18(2), 353-374.

Swindle, R., Kroenke K., \& Braun, L. (2001). Energy and improved workplace productivity in depression, in Irina Farquhar, Kent Summers, Alan Sorkin (ed.) Investing in Health: The Social and Economic Benefits of Health Care Innovation (Research in Human Capital and Development, Volume 14), (pp.323 - 341). Emerald Group Publishing Limited.

Tabachnick, B.G. \& Fidell, L.S. (2007). Using Multivariate Statistics (5 $5^{\text {th }}$ edition). New York: Allyn and Bacon.

Tett, R.P. \& Meyer, J.P. (1993). Job satisfaction, organizational commitment, turnover intention, and turnover: path analyses based on meta-analytic findings. Personnel Psychology, 46, 259-293.

Tonsing, K.N. (2014). Psychometric properties and validation of Nepali version of the Depression Anxiety Stress Scales (DASS-21). Asian Journal of Psychiatry, 8, 63-66.

Wheaton, B., Muthen, B., Alwin, D. F. \& Summers, G. F. (1977). Assessing Reliability and Stability in Panel Models. In David R. Heise (Ed.). Sociological Methodology Jossey-Bass (pp. 84-136). San Francisco.

Williams, L.J. \& Hazer, J.T. (1986). Antecedents and consequences of satisfaction and commitment in turnover models: a reanalysis using latent variable structural equation methods. Journal of Applied Psychology, 71(2), 219-31.

Wolfe, M.T. \& Patel, P.C. (2019). Labor of love? The influence of work-conditions among self-employed and work stress. Journal of Business Venturing Insights, 11, Article e00118.

Yao, Y.H., Fan, Y.Y., Guo, Y.X., \& Li, Y. (2014). Leadership, work stress and employee behavior. Chinese Management Studies, 8(1), 109-126.

Yıldırım, A., Boysan, M., \& Kefeli, M.C. (2018). Psychometric properties of the Turkish version of the Depression Anxiety Stress Scale-21 (DASS-21). British Journal of Guidance \& Counselling. 
Zagenczyk, T. J., Purvis, R. L., Cruz, K. S., Thoroughgood, C. N., \& Sawyer, K. B. (2020). Context and social exchange: perceived ethical climate strengthens the relationships between perceived organizational support and organizational identification and commitment. The International Journal of Human Resource Management, 1-20.

Zellars, K.L. (2007). Social Anxiety: An Overlooked Variable in the Organizational Stress Literature, in Pamela L. Perrewé, Daniel C. Ganster (ed.) Exploring the Work and Non-Work Interface (Research in Occupational Stress and Well-being, Volume 6), (pp.1 - 33). Emerald Group Publishing Limited. 